\title{
Analysis of How Tesla Creates Core Innovation Capability
}

\author{
Hyeonjoo $\mathrm{Kim}^{1}$ \\ ${ }^{1}$ Coventry Business School, UK \\ Correspondence: Hyeonjoo Kim, Seduck Villa 301 ho, Sajik-dong, Dongrae-gu, Busan, 47872, South Korea. \\ E-mail: degree1682@gmail.com
}

Received: April 2, 2020

doi:10.5539/ijbm.v15n6p42
Accepted: May 1, 2020

Online Published: May 12, 2020

URL: https://doi.org/10.5539/ijbm.v15n6p42

\begin{abstract}
Tesla as green technology is new concept to current market. Current conventional market is significantly comparative. As a new comer to existing difficulty to enter the market, the company demonstrates significant innovation in various ways. Thus, Tesla has different concept of management and marketing to the market place. The company demonstrates online strategy and vehicle's IT connected system. To improve integration of technology, the main firm acquired solar panel and installing firms. The company's pathway to manage the organization and approach to its consumers would bring significant understanding in terms of business and management.
\end{abstract}

Keywords: Innovation management, Innovation $4 p$, leadership, innovation organization, organizational leadership, transformational leadership, transactional leadership, leadership competencies

\section{Introduction}

Global consumption for fossil fuel energy is around $82 \%$ and demand for the energy had been increased more than twice from 1971 to 2015 . This phenomenon has significant impact on carbon dioxide emissions which had been skyrocketing from 1950. Carbon dioxide emission caused by transportation reached $25 \%$ in 2015 and among transportation emission, 28\% was emitted from China and 17\% was emitted from North America. In terms of saving the planet, introducing electric car seems to be remedy for worsened environment (IEA, 2017).

Turning point that auto industry paid attention to electric vehicle was one of leading automobile maker, Volkswagen was hit by diesel emission scandal and fined for \$ 15 billion. One of significant solutions to maintain in current market place was introducing electric power engine (Focus, 2017).

Not only the world faced negative perspective on carbon dioxide emission which causing climate change and other harmful effects, but also the energy consumption for industrial activities caused major concern of depletion of oil reservoir (Bilbeisi \& Kesse, 2012, p. 2017). Price of crude oil was peak point in 2014 and it was around $\$ 96.2$ per barrel. Years later, the price was plunged as around \$ 56 per barrel in 2018. However, anticipation of the World Bank for the price of crude oil is gradually increasing from 2016 to 2030. High price of petrol can be one of reasons for shifting from conventional engine power to electric power engine (TheWorld Bank, 2018).

Carbon dioxide problem and high price of gasoline are tremendous forces to consider other alternative resources to power the engine. There is trial to set recharging stations for electric vehicles, supported by the International Economics Forum of the Americas in Montreal, Canada (DUNN, 2016). As above indicated, some of researchers in these fields suggest that big auto producers such as GM, Toyota and some others to shift their manufacturing line from conventional engine to electric car (COHN, et al., 2015).

Two concerns as carbon dioxide emission and rising price of petrol might be significant reason for growing demand for electric car in traditional car market place. Hyrid and electric vehicle demand of the United States of America was $27 \%$ out of total global demand for hybrid and electric car and those of $16 \%$ was electric car demand. Consumption for electric car is growing constantly. 504,060 eco friendly car was sold and General Motors, Nissan, Tesla and Toyota are 4 leading electric car manufacturers in the world (MarketLine, 2017).

Among GM, Nissan, Tesla and Toyota, particularly Tesla is very unique in style. This manufacturer is the fastest growing electric car producer by key financial ratios. Revenue growth of the company was significantly lofty and actual grow was 102.5, 387.7, 58.8, 26.5 and 73.0 (\%) from 2012 to 2016 which sum of assets was extremely inflated during the period (MarketLine, 2017). Tesla's technology of autopilot system and different 
concept for distribution channel are the facotrs which CEO of Tesla, Elon Musk said 'Tesla is Silicon Vally company, if we are not the leader, shame on us'. Tesla is new comer to existing vehicle market place and it demonstrates valued organizational structure among all auto manufacturers (Stringham, et al., 2015). Tesla as business organization is one most innovative company in the world (Forbes, 2016).

Elon Musk, Martin Eberhard and Marc Tarpenning are keen engineers whom founded Tesla Motors, Inc. in 2003 (Chafkin, 2016). Performance of the organization is to design, develop and produce tech savvy electirc car, powertrain components and disturibute products (MarketLine, 2017). Geographic segmentation was classfied as North America, Europe, Middle-East and Asia/Pacific by Tesla (Tesla, 2018).

CEO of Tesla, Elon Musk who is from South Africa and is a Canadian-American business person is one of most intriguing person as cameo character of movie, Iron Man and founder of several advanced tech companies (Vance, 2013).

Products of Tesla are electric vehicles such as Model S, Model X, Model 3 and roadster and energy solutions such as Solar Panels, Powerwall and Solar Roof. As well as super charger is sold as custom order and fashion items and lifestyle items are sold in Tesla's website (Tesla, 2018).

Marketing strategy for branding as introducing Model 3 after successful market entrance of other models which is previous winning branding strategy is key standard-tier decision and new premium tier. Similarity in the branding could influence new product category and newer products followed by previous productions are diversification and improvement for customer satisfaction (Rahman, 2014).

There is significant difference between Tesla and conventional auto makers. The website of Tesla includes forum page and it is open to public for participation and discussion abot Tesla. However, other manufacturers offers only traditional franchise dealership as buying process (Dana Hull, 2012, p. 2017).

Distribution channel of Tesla is significantly comparable to those of existing auto makers. Market approach of Tesla as providing showroom and online market is distribution strategy (Bilbeisi \& Kesse, 2012, p. 2017). Advanced innovation for distribution shortens process and time of purchase tremendously (Dana Hull, 2012, p. 2017).

As new comer and new electric vehicle manufacturer, Tesla would have tremendously difficulty in penetrating into existing conventional automobile market (Stringham, et al., 2015).

Significant barrier such as economies of scale, established network for distribution, fueling and service indicates that it seems to be not possible mission to success in car market. Consideration for introducing electric car faces that the higher investment requirements and higher the barriers of entry which disrupting innovation or start-up business. Although successful penetration into the market is not guarantee for successful auto maker in highly comparative car industry, Tesla's attitude seems to be doing the best to overcome disadvantage of new entry and the company had succeed to enter the present market and distributed significant amount of electric cars. The statement, 'Our goal when we created Tesla a decade ago was the same as it is today: to drive the world's transition to electric mobility by bringing a full range of increasingly affordable electric cars to market' was delivered from CEO of Tesla (Stringham, et al., 2015).

Tesla's high tech products took significant attention from early adopters which spurred penetration to niche market (Bartman, 2015). Installation inside car of touch screen control pad with many functions and large size represents cutting-edge IT tech for products and the company of brand image (Vance, c. 2012, p. 2017). The feature of voice command for autopilot system is effective way of cruising on the road which was preferred by many customers (Frick, 2016). Smart devices and software, co-response with drivers are tremendously valuable (Hansen, 2015). The touch screen control pad is 17 inch information system and installed on the dash board which operates sun-roof control, music streaming, navigation and map displaying and other functions within smart applications. Tesla is leading Silicon Valley's high tech auto maker (Vance, c. 2012, p. 2017).

\subsection{Personal Reason for Research}

A book of (Rifkin, 2003) had inspired me thinking of worse thing happened by fossil fuel and having interests in alternative energy. Research of Tesla would be solving the intellectual curiosity. Tesla's innovation and the ways to manage the organization would be considerable study in terms of green tech management.

\subsection{Research Questions and Objectives}

Purpose of research questions and objectives; understanding of innovation management of Tesla will specifically look into certain areas of management subjects. After then, market analysis for electrical vehicles. Process will move onto Tesla's innovation in terms of leadership for electric vehicle then focus on Tesla's key elements 
strategy. The, process will be delving down what is competitive advantage for Tesla over other car producers. Final process will illuminate overcoming Tesla's performance in the market within economics scope for business. These questions specifically will narrow down to precise conclusion with well-established strategy models.

\subsection{Questions}

1. What are key concepts of innovation core capacity?

2. How does leadership influence innovation in the organization of Tesla?

3. How does external factors force innovation for Tesla?

\subsection{Objectives}

1. To carefully criticize innovation management with current issues.

2. To critically analyze leadership in Tesla's organizational environment.

3. To meticulously discuss external analysis within economics scope.

4. To carefully analyze case study of Tesla.

1.5 Aims

To carefully delve down and analyze the case of innovation management of Tesla.

\section{Literature Review}

In order to conduct critical literature review, Tesla's innovation capability would be reviewed.

According to (Forbes, 2018), Tesla has been listed as second most innovative company in the world. Tesla as new comer, it has achieved world $42^{\text {nd }}$ growth champion. Tesla indeed shows greatness in innovation both technology and management. According to (Forbes, 2016), it is the most innovative company in the world. The firm's innovation is one of most valued in current market and it is one of leading company.

PayPal founder Elon Musk started few startup companies such as Zip2, X.com, Space X, Tesla and funded the firm; Everdream and SolarCity. One of his company Tesla is the firm which manufactures electric vehicles (Vance, 2013).

Tesla is the only company that is vertically integrated energy company in the world. The firm is vehicle manufacturer which produces autopilot system mounted electrical sedans and SUVs. It also deals with energy storage system and all relevant area of solar power generation which all these factors are clear reasons to be differentiation for Tesla from other vehicle manufacturers (Tesla, 2016).

\subsection{Business Model for Tesla}

Table 1. Business model canvas of Tesla

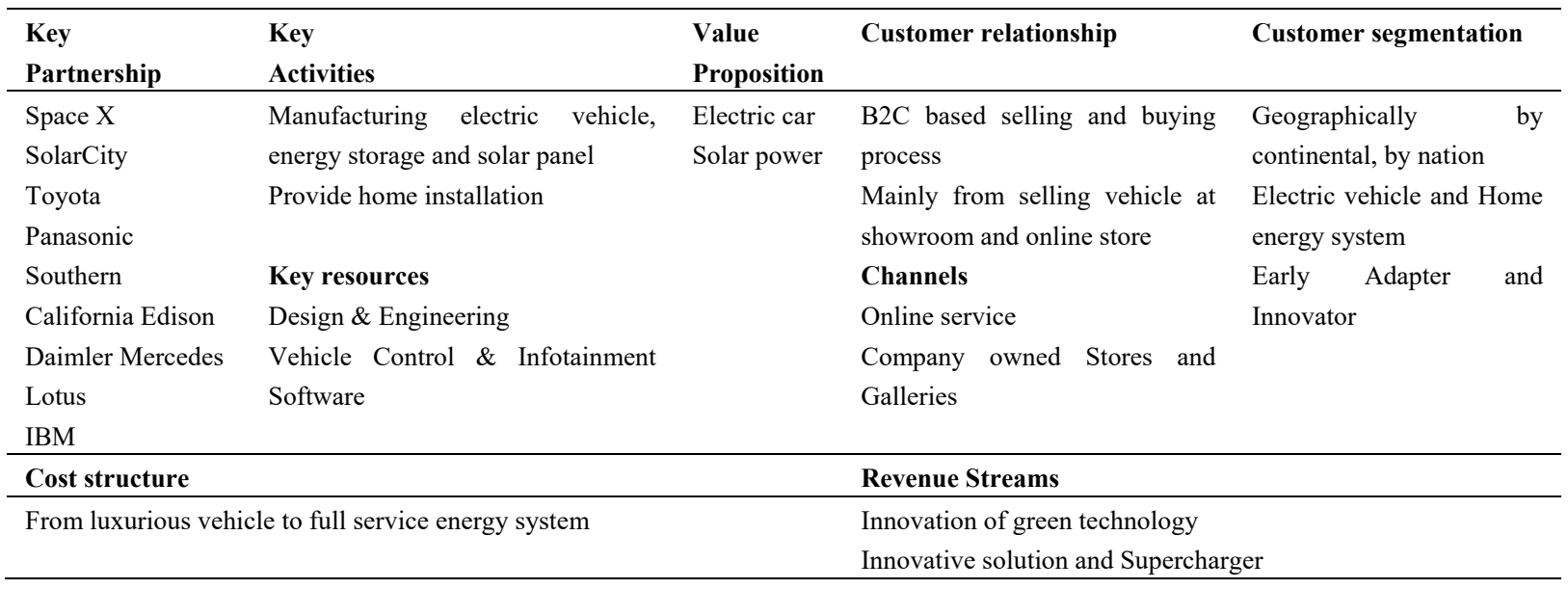

Tesla is can be very simple organization however, it is somewhat integrated body of few organizations which produces cutting-edge technology (Tesla, 2018). Tesla is one of most innovative companies in the world with analysis of business model (Forbes, 2016). The company has sub-categories for green tech products and it innovates most efficient driving and has future-oriented management. Studying of (CENDROWSKI, 2017), 
(Anon., 2017), (Tesla, 2016), (Tesla, 2018), (MarketLine, 2015) highlights that the firm is also one of the well-known electric vehicle provider in the world and it has been globally recognized.

- Tesla's main key activities are producing electric vehicle, solar power panel and power storage wall as well as it offers financial service and hardware installation (Tesla, 2016). As well as it designs future transportation such as electric truck (Vance, 2017). Tesla used to make roadsters and sedans however, today Tesla website offers 4 categories; Model S, Model X, Model 3 and Energy (Tesla, 2018). Roadster previously introduced to US market place was discontinued while new models were released into market place. Model $\mathrm{S}$ is typical sedan with electric power engine, four-door and huge touch screen panel in dashboard with autonomous driving system (Tesla, 2016). Second product followed by Model S is Model X which is Tesla's SUVs then it comes with last vehicle product that is Model 3 . This model that recently introduced is less luxury by comparison to other models and it will not be available until mid-to-late 2017 (MINGIS, 2016).

- Tesla's innovation for a software update made viable autonomous driving in reality which is significant key resource for the firm (Bradley, c. 2012, p. 2017).

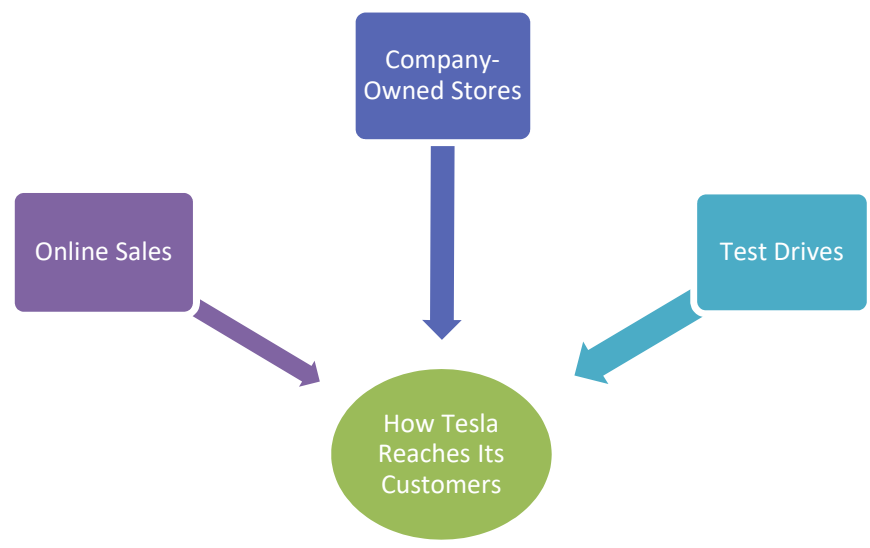

Figure 1. Tesla's contact points with customers

Tesla has somewhat different approach to customer, traditionally auto manufacturer has distribution channel which is called car dealer and dealer used to be communication for customer to its firm, but Tesla has showroom and website which has functions to communicate and buy online (Hoffman, c. 2012, p. 2017). Page updates of Tesla's website provides user's interface which user can upload their story about Tesla experience as well as firm press its own article on the page (Tesla, 2018). This channel innovation is significant. Tesla has its own showrooms and website for sales. Tesla delivered its first car to New Zealand while it does not have dealership but while ongoing for opening of Tesla store (Anon., 2017). Tesla sales is growing in China. Customers ordering cars from both dealership and website as well as many customers are approaching to Tesla store (CENDROWSKI, 2017).

Tesla's value positioning highlights with powerwall storage system which is first innovation in the market. As EV producer, it has shifted for energy producing and storage manufacturer by acquiring partner firm, SolarCity (Giulietti, et al., 2015). Tesla website offers Energy which provides Solar panels, Powerwall, and Solar roof to generate and store energy for personal usage and this can power Tesla's electric vehicle (Tesla, 2018).

Tesla was founded by some of Silicon Valley's engineers in 2003 in order to cut off carbon dioxide emission, is energy innovation leader and is power generator firm. Its firm operates assembly factory in Lathrop, California as well as firm operates manufacturing tentacles in Tilburg, Netherlands. Tesla is also going for wing its production by building new Gigafactory to increase productions in Reno, Nevada. Its facilities are growing and eventually it will cause mass production of vehicle (Bilbeisi \& Kesse, c. 2012, p. 2017).

- Cost structure shows that price of Tesla is quite higher. Discontinued the roadster was price as $\$ 109,000$ (USD), Model $\mathrm{S}$ is priced as $\$ 90,000$, Model $\mathrm{X}$ is priced as $\$ 90,000$ (EST.) and Model 3 is priced (DYER \& FURR, 2015). These products are considered to be luxurious and its competitors are such luxury brand BMW X5, Porsche Cayenne, Volvo XC90 and Audi Q6 (Fehrenbacher, 2015). 


\subsection{Tesla's Segmentation, Targeting and Positioning}

\begin{tabular}{ll}
\hline Segment & Electric vehicle and Energy generator, storage \\
\hline Target Group & Middle class, Early Adaptor, Innovator \\
Positioning & Global presence, Successful merge of relative firms, services for world-wide \\
\hline
\end{tabular}

\subsection{Product Portfolio}

ELECTRIC VEHICLE

Tesla uses only electric power for operation but SolarCity which produces solar power panel was not belong to Tesla beforehand. When SolarCity was in public in later of 2012, its stock hit only $\$ 8$ and it surged $47 \%$ in first day of trade and it eventually hit $\$ 86$ in early of 2014 and had more than 70,000 customers. The firm manufactures and serves mainly rooftop designs, panels, and installation, hired 150 employees (mainly construction workers) and made about 70 systems per month in Northern California. According to Elon Musk's presentation merge of SolarCity was one crucial achievement for such green tech firm which brought about $85 \%$ of shareholder's agreement. Last October at the Universal studios' back lot in California, these two firms were united as a joint-firm as one. One advantage over other renewable energy is it requires less grid dependency which can reduce cost of maintain (Carr, 2017). Tesla can generate energy during the day hours, store it and spend it during night hours. Its ability takes only $16 \%$ which is behind of conventional panels, but it has more cost efficiency by comparison stated by product manager, Chris Fisher (Vance, c. 2012, p. 2017). For battery pack, it is opening $\$ 5$ billion dollars plant with Panasonic in Nevada (Giulietti, et al., 2015). This is firm's vertical integration strategy.

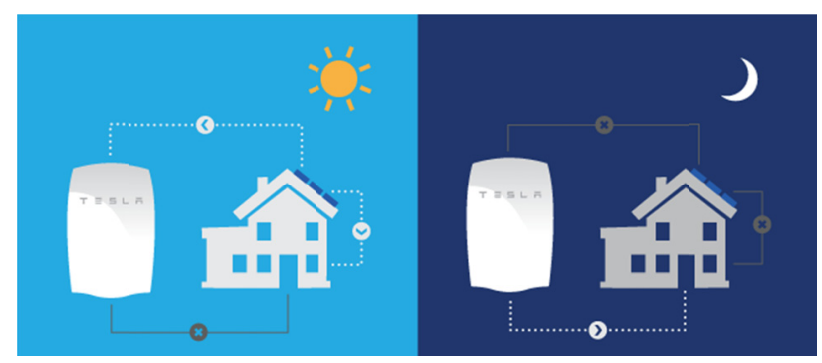

Figure 2. Tesla's energy circulation - energy saga 


\subsection{Target customers}
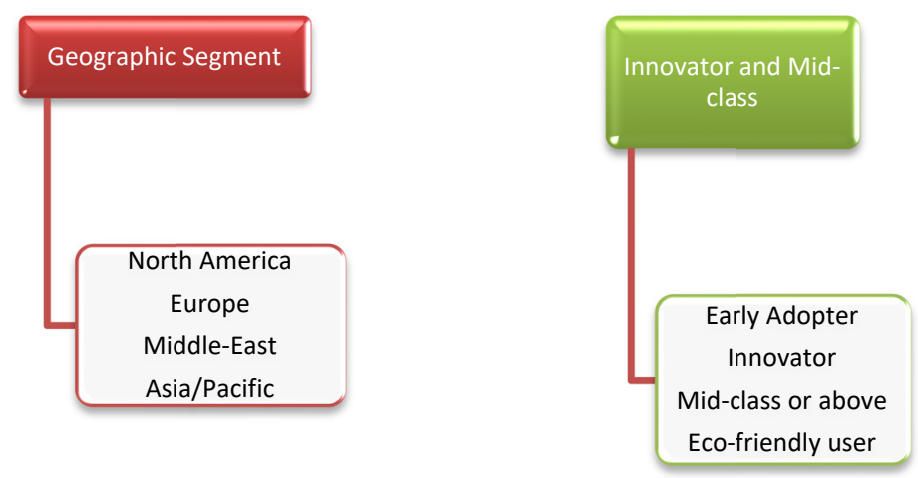

Figure 3. Segmentation strategy of Tesla

\subsection{Innovation Dimension framework (4 Ps)}

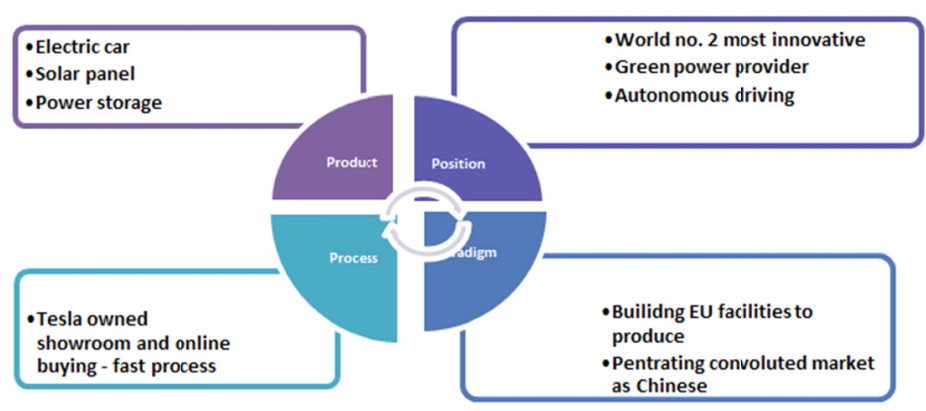

Figure 4. Innovation dimensions (4 Ps)

According to (Vance, c. 2012, p. 2018), a bus company adopted Tesla's innovation model for aim.

Product of Tesla

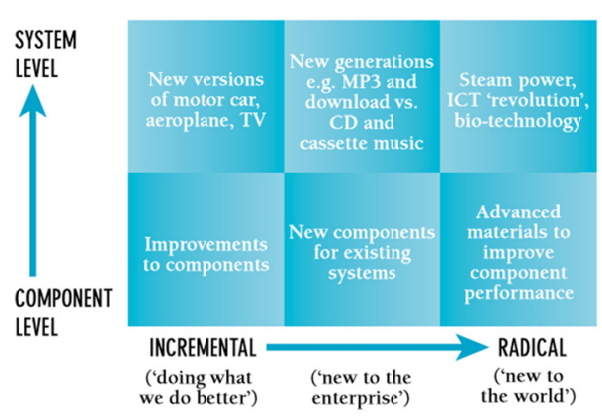

Figure 5. Dimension of Innovation

Source: Tidd et al. (2005).

By studying of (Tidd, et al., 2005), Tesla's products can be defined as high system level and incremental innovation with production of electric cars and energy solution. Inside of its technology such as autopilot program can be referred to be radical innovation.

By review of (KOSOWATZ, 2017), Tesla has significant innovation on battery which is potential power for Tesla's engine. Innovation of battery pack makes products more affordable. Partnership with Panasonic brought 
about high innovation. By studying of the firm's report (Tesla, 2016), Model S and Model X are the longest range of all of sedan and SUV in the world. With reduced cost, its range is almost 500 miles (Bilbeisi \& Kesse, c. 2012, p. 2017)

By review of (FRPT, c. 2012, p. 2016), there was clear issue reported from Der Spiegel, Germany with technical security issue but there was no investing procedure against Tesla. According to (Vance, 2014), some Silicon Valley firms has been working for raise quality of software. The enhancement on quality of software included with availability of low price, powerful processors and sensors and more reliable mechatronics for viable operating system. The strengthening combination of hardware with software brings about Tesla's product advantage in products (Vance, 2013).

Tesla's cars show off with high price as luxurious sedan (Fehrenbacher, 2015). However, Tesla initialized to produce low priced mid-size vehicle to represent to lower income consumers (ANDERSON, 2014) \& (MINGIS, 2016). As well as, Tesla designs high-performance and tech savvy products (Tesla, 2016).

\section{- Process of Tesla}

According to (Stringham, et al., 2015), to penetrate existing automobile industry has the barriers to entry. There is significant initial burning which is excessive cost of entry, economics of scale and network effects from distribution. The researcher (Bartman, 2015) indicates that the firm did not reach successful scale with high cost.

Tesla has added additional Gigafactories. Gigafactory 1 is outside of Reno, Nevada and other is in upstate New York. There is consideration of construction in Australia, China, Japan, Sweden and east coast of US (Knights, 2017). Gigafactory 2 is in Buffalo, New York (Carr, 2017).

To overcome economy of scale, the firm operates oversea, its European headquarter and facilities are located in Amsterdam and Tilburg, the Netherlands. For reliable supply chain, the firm developed close relationship in terms of procurement of cells and some key system parts from around the world (Tesla, 2018).

In order to bring more valued products, Tesla has key partnership with Panasonic for increase quality and decrease the cost (KOSOWATZ, 2017).

\section{- Position of Tesla}

According to (Cornell \& Damodaran, c. 2012, p. 2017) it was established in 2003 as electric car producer and it went on public on June 2010.

By review of (FRPT, c. 2012, p. 2015) and (FRPT, c. 2012, p. 2016), Tesla offered deal to acquire SolarCity shares worth of $\$ 2.6$ billion. The shareholder approved merge with SolarCity (Carr, 2017).

Tesla's positioning for expansion added Solar Panels, Powerwall and Solar Roof. As well as its business expanded to installation for home owners (Lambert, 2018).

These can be crucial factors for innovation positioning and according to (Forbes, 2016), it is the most innovative company in the world.

\section{- Paradigm of Tesla}

Tesla denies conventional distribution approach and it sells directly to customers (Chronowski, et al., 2017).

Tesla brought the network and distribution effect as its Showrooms, Galleries, Pop-up shops, Website and department stores (McCorvey, 2016).

Tesla's innovation management provides faster and more reliable purchasing (Dana Hull, c. 2012, p. 2017). Conventional buying process takes 8 steps. However, new step reduces procedure as visiting a showroom or website, selection with deposit, waiting for order, paying and delivery.

\subsection{Evaluation of Components of Innovative Organization with Tesla}

To integrate of theoretical innovation management models into the analysis of Tesla, there are seven factors for review. 


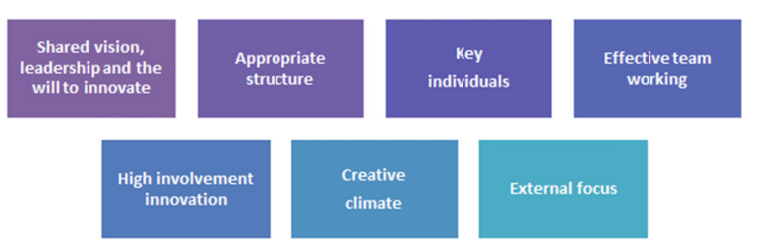

Figure 6. Components of Innovation organization

\subsubsection{Shared Vision, Leadership and the Will to Innovate}

Tesla addresses that the faster the world stops using on conventional energy and moves toward zero-emission future, the better. The firm's 'Secret Master Plan' in 2016, introduced low priced Model 3. Gigafactory 1 is designed as reducing battery cell cost and production is willing to meet innovation goal as well as creating numerous jobs. The firm's vision delivers affordable, clean transportation, clean energy production and will to be more powerful of those. It is vision, the future Tesla want (Tesla, 2018).

Co-founder, Martin Eberhard had vision for Tesla which is 'to bring their first car "to the market quickly and efficiently" (Stringham, et al., 2015).

The company's main mission is to accelerate the world's transition to sustainable energy (Tesla, 2018).

\subsubsection{Appropriate Structure}

In mainland, Tesla manufactures in California and battery production is in Gigafactory 1 . The firm maintains European headquarter and facilities in the Netherlands (Tesla, 2016).

By review of (Carr, 2017) and (Tesla, 2018), it is clear that the firm's sub-departments are Electric Vehicle, Solar Panel, Power Wall and Solar Roof as well as according to (Lambert, 2018), it has installation department.

By review of (Chronowski et al., 2017), (Dana Hull, 2012, p. 2017) and (McCorvey, 2016), Tesla's structure shows that it has marketing sections such as Showrooms, Galleries, Pop-up shops, Website and department stores. The company is distributing its products through mainly two different approaches as off-line shop and online website.

By review of (Bradley, c. 2012, p. 2017), indicates that the firm maintains software system in organization. In orders to achieve self-driving system, car has to be connected vehicle and this system requires real-time updates (Kight, 2016). In terms of IT, this car has venerability from hacking.

In the end of 2016, Tesla had employed 17,782 full-time workers and SolarCity had employed 12,243 full-time workers. The company considers relationship with employees is positive which highlights HR management is significant. The company also maintain viable chain supply from the world (Tesla, 2016). R\&D center is Space X compounded (Vance, 2013).

The appropriate structure can be hardware (EV, energy), software (autopilot, system), marketing (online, offline), HR, chain supply, R\&D and geographical branches.

2.6.3 Key Individuals

Group of engineers such as Elon Musk, Martin Eberhard and Marc Tarpenning founded Tesla (Chafkin, 2016). CEO Elon Musk is a 46 years old South Africa-born, Canadian American leader (JOHNSON, 2017).

Elon Musk's previous achievement in his career is founding of online transaction platform PayPal. When users online for shopping in eBay, money transaction is getting though this PayPal program. It was acquired by eBay and this gave Elon Musk tremendous fortune (Vance, 2013). The car that ordered by customer will be delivered. Tesla's marketing management approaches innovative online sales which highlights online sales (Hoffman, c. 2012, p. 2017).

Elon Musk starred Hollywood role model as main character of Iron man which shows high popularity. As well as his achievement of founding Space $\mathrm{X}$ is significant (Vance, 2013). According to (Hansen, 2015), CEO himself is face of the company and significant brand.

\subsubsection{Effective Team Working}

By review of (Tesla, 2018), both Tesla and SolarCity hired numerous employees that is total 30,025 people and have not experienced work stoppages. Plenty of employees' relationship is considerable. 
According to (Vance, 2013), for R\&D department Tesla and Space X are cooperating as one team. Both companies are high technology and science involved and this harness the firms' innovation.

By review of (Wrolstad, 2017), Tesla have operated on approximately 1,300 team projects worth $\$ 70$ million in 37 global places for technology, research, finance and marketing. Projects fields are mainly education, health and community resiliency. Tesla addressed that 'Our employees see this as a rare opportunity to cooperate with NGOs and social enterprise on the ground.

Tesla highly involved with other companies such as Lotus and Panasonic to produce vehicle which team working effectively involves with partnership companies (Stringham, et al., 2015).

2.6.5 High Involvement Innovation

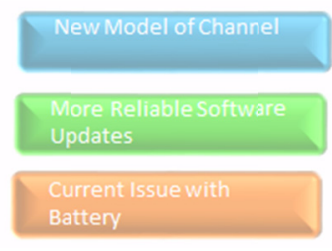

Figure 7. High involvement innovation of Tesla

Tesla has dispute with Michigan for the firm claims that it should not be mandatory to distribute cars though conventional dealer network model (Chronowski, et al., 2017).

Traditional dealers addressed that prohibiting Tesla's marketing approach is 'customer protection' and creation of competition in dealership distribution is to protect from manufacturers price-gouging. GM claims that approving Tesla for direct distribution would be a distinct competitive advantage and would cause of significant disparate impact (CRANE, 2014).

Tesla has tremendous initial cash burning (Swiegers, 2017). Tesla's marketing strategy does not cover for advertisement (Tesla, 2016). These factors refer to implication of necessary of high involvement innovation in marketing ways.

By review of (Hansen, 2015), (Hull, c. 2012, p. 2018) and (Hull, et al., c. 2012, p. 2017), Tesla leverages technology in innovative ways. The effective network to reach consumer in innovative paradigm ways is mixing of branding technology. In spite of dis-accord, the firm has performed direct approach to consumers (ex, online selling).

According to (Frick, 2016), there is anti-trusting autopilot system with accident on the road. In orders to achieve self-driving system, car has to be connected vehicle and this system requires real-time updates (Kight, 2016). Unlikely Google, Tesla has that consumers and their vehicles are widely distributed test fleet. The way of innovation involves with software updates (Bradley, c. 2012, p. 2017).

There is significant issue for Tesla with that battery problem (Chafkin, 2016). Tesla has key partnership with Panasonic in terms of high involvement of innovation for battery issue (KOSOWATZ, 2017).

\subsubsection{Creative Climate}

By review of (Bilbeisi \& Kesse, c. 2012, p. 2017), Tesla inventory management reduces cost to minimize risk by storing minute inventory. This management delivers tremendous advantage as saving \$30 million and minimizes logistic costs in 2013. Saving on management goes toward R\&D which contributes the firm with significant innovation climate.

By studying of (Vance, 2013), (Stringham, et al., 2015) and (Wrolstad, 2017), Tesla harnesses creative climate by cooperation with partnership companies. Global projects and $R \& D$ are main task in ways to develop innovative environment.

\subsubsection{External Focus}

Tesla has reputation for world most innovative company (Forbes, 2016). The firm's cutting-edge technology introduced highest range for single charge. It has solid brand name founding and maintains good reputation among consumers and receives positive feedback (Mangram, 2012). Tesla's innovation model is other company's epitome (Vance, c. 2012, p. 2018). There is significant awareness of Tesla globally as well as second largest economy, China (Anon., 2017), (CENDROWSKI, 2017). 


\subsection{Discussion to the market conditions question}

\subsubsection{Crude Oil Price Forecast}

Oil price could be one crucial point for customer to decide among conventional fossil-fuel engine, hybrid car and full electric vehicle. Unit of this chart is $\$ / b b l$.

Table 2. World Bank Crude oil, avg Price Forecast (nominal US dollars), (WordBank, 2017)

\begin{tabular}{lcllllll}
\hline & $\mathbf{2 0 1 4}$ & $\mathbf{2 0 1 5}$ & $\mathbf{2 0 1 6}$ & $\mathbf{2 0 1 7}$ & $\mathbf{2 0 1 8}$ & $\mathbf{2 0 1 9}$ & $\mathbf{2 0 2 0}$ \\
\hline Price & 96.2 & 50.8 & 42.8 & 53.0 & 56.0 & 59.0 & 60.0 \\
& $\mathbf{2 0 2 1}$ & $\mathbf{2 0 2 2}$ & $\mathbf{2 0 2 3}$ & $\mathbf{2 0 2 4}$ & $\mathbf{2 0 2 5}$ & $\mathbf{2 0 3 0}$ & \\
Price & 60.9 & 61.9 & 62.8 & 63.8 & 64.8 & 70.0 & \\
\hline
\end{tabular}

By review of (WordBank, 2017), average crude oil price is $\$ 56$. The crude oil price is currently $\$ 56.0$. By anticipation of price fluctuation, it will slightly rise in the future.

However, crude oil price is $\$ 96.2$ in 2014 . By comparison to 2014, crude oil price does not provide green light for electric vehicle sales.

2.7.2 Global EV Outlook, International Energy Agency

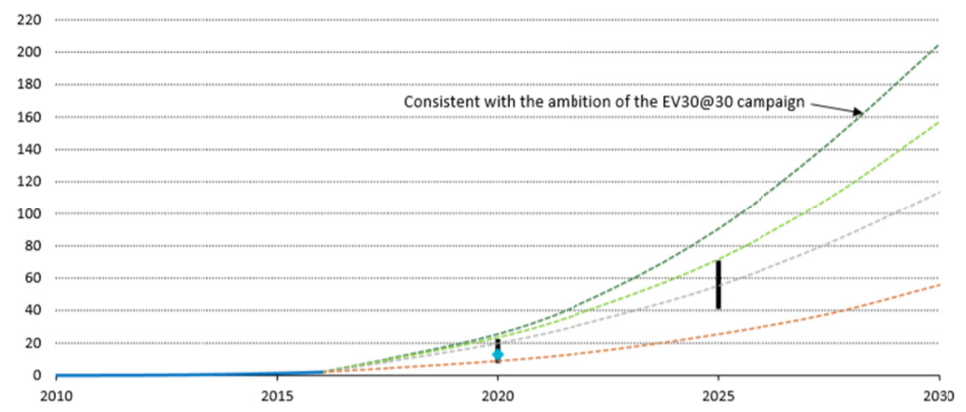

Figure 8. Deployment scenarios for the stock of electric cars to 2030

According to (IEA, 2017), anticipation on electric vehicle sales in the future is positive. There are 4 lines in the chart. From the highest, these are scenarios by IEA B2DS (The Beyond $2{ }^{\circ} \mathrm{C}$ Scenario), IEA 2DS (The $2{ }^{\circ} \mathrm{C}$ Scenario), Paris Declaration and IEA RTS (The Reference Technology Scenario).

\subsubsection{Lower Price of Electric Vehicle May Attract More Demand}

Tesla's lower priced vehicle, model 3 has been introduced which may attract more consumers in various class (MINGIS, 2016). There is innovation ongoing to reduce battery which may impact on lower price for Tesla products (KOSOWATZ, 2017). As well as, Gigafactories would bring about economy of scale in the future which may lower the price in terms of expansion of market share for future aspect (Stringham, et al., 2015).

\section{Analysis}

\subsection{Internal Analysis of the Organizational Leadership}

Tesla was established by Elon Musk, Martin Eberhard and Marc Tarpenning (Chafkin, 2016). Elon Musk is the co-founder and CEO and Product Architect of Tesla. He was born in South Africa and is a Canadian American leader (JOHNSON, 2017).

By analysis of (Tesla, 2018), Elon Musk's role in Tesla is tremendously crucial which involved with various ways of activities such as all product development, engineering and design of vehicles, battery products and solar roofs. He is the top of main management and this indicates that his leadership must be noteworthy influence for Tesla.

To carefully delve down how successfully CEO, Elon Musk leads would be one of the best research analysis for Tesla's internal strengths or weakness. 


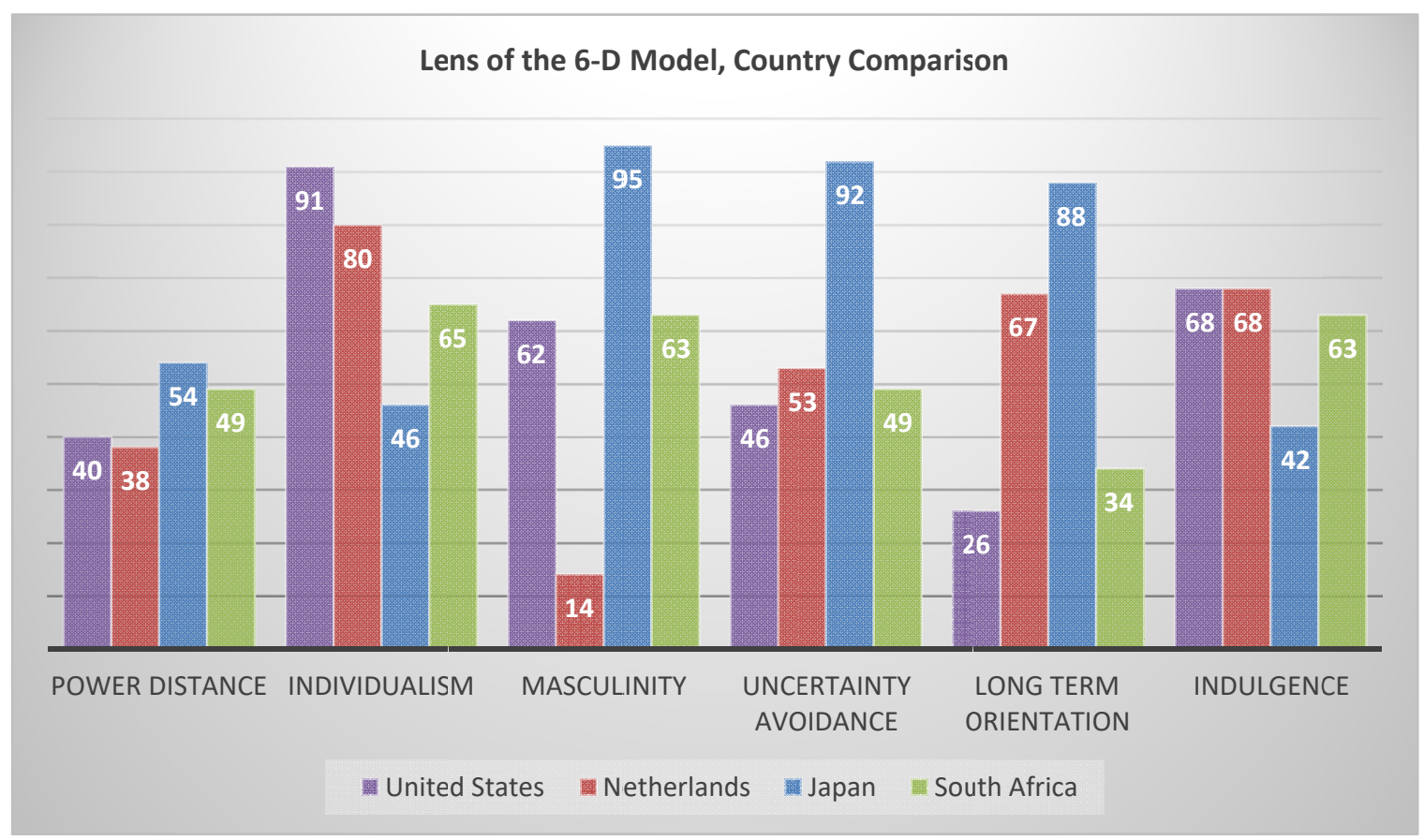

Figure 9. Cultural Dimension, Lens of the 6-D Model, Country Comparison (Hofstede, 2018)

There are 4 countries being selected in this chart. South Africa is birth place of Elon Musk (JOHNSON, 2017). The United States is where the company was founded and where are main offices. Most considerable partnership for Tesla is involved with Japanese companies such as Panasonic and Toyota (KOSOWATZ, 2017). Tesla has European headquarter and manufacture facilities in the Netherlands (Tesla, 2016).

By analysis of (Hofstede, 2018), South Africa where Elon Musk was born has the lowest individualism. Elon Musk is one of founder and he manages in wide scope (Tesla, 2018). His considerable work can be interpreted as sacrificed and devoted for the organization. His leadership would be more reliable.

By analysis of (Hofstede, 2018), the United States where are main offices and facilities, has highest individualism and lowest long-term orientation. According to (Papierz, 2017), one of Silicon Valley's company, Apple's work place usually does not offer for permanent job. Employees can be laid off sometimes. There are always in and out in this environment. The life cycle of products highlights that it is based on short term orientation. Tesla can be defined as one of Silicon Valley firm with high reputation of IT tech. Hiring and firing employees to achieve higher technology maybe significant innovation paradigm. High individualism can affect negatively for team projects; however, Tesla has R\&D center with Space X (Vance, 2013). For research and development, high individualism could contribute with positive ways in terms of focus on research projects in software. ICT revolution is radical and system level of innovation (Tidd, et al., 2005).

By analysis of (Hofstede, 2018), Tesla has issue with battery problem, the vehicle has to be charged and it takes longer time than filling with gasoline. Tesla has key partnership with Panasonic and Toyota which are Japanese companies. Tesla and Panasonic have worked for innovation of battery (KOSOWATZ, 2017). Japan has the highest power distance. This factor can be interpreted as working with Japan for R\&D at battery maybe suitable. Japan has the lowest individualism which might be team projects on Global projects and R\&D are suitable. Japan has the highest masculinity is the drive for excellence and perfection in their material production (monodukuri). This factor leads that Japan is suitable for urgent issue to solve battery tech. Japan has the highest uncertainty avoidance which indicates that the Japanese team maybe considerable for R\&D. The nation has also highest long-term orientation. Unlikely Silicon Valley companies' short-term orientation management, R\&D is supposed to be longer term which highlights that Japan is considerable to be R\&D partner (Papierz, 2017). Battery on vehicle is incremental innovation (Tidd, et al., 2005).

By analysis of (Hofstede, 2018), the Netherlands has the lowest level of power distance. The nation fosters Tesla's European headquarter and facilities. This factor indicates that it may be considerable level to be harmonized among management and other work forces (Tesla, 2016). The nation has the lowest masculinity and 
the highest indulgence which indicates that the Netherlands is suitable place for office work. Cultural dimension clearly highlights that the Netherlands is suitable place for head office and some facilities. The highest indulgence rate maybe the reason why the Netherlands has $2^{\text {nd }}$ highest consumption on Tesla products in Europe (Jones, 2014).

By analysis of statements above, concept of work place and leadership of Tesla which made of very independent and short and fast responding firm's culture by employees and this is one of most crucial factors for leadership in terms of software updates in the United States. CEO, himself is deeply involved with inter-communication with consumers and direction for consumers by online media as Tesla's branding image. However, it is more incremental leadership in other nations with hardware perspective.

Table 3. Maria Pressentin - universal leadership approaches \& cultural dimensions

\begin{tabular}{ll}
\hline & Coaching Survey \\
\hline $\mathbf{1}$ & $66 \%$ of CEO feels lonely and do not take any message from outside \\
$\mathbf{3}$ & $\begin{array}{l}\text { All CEOs wants to be coached } \\
\text { bven } 60 \% \text { of CEO answers that they want progress to be secret, others share, and scholars advise for keeping it transparent to be the }\end{array}$ \\
$\mathbf{4}$ & $\begin{array}{l}\text { Most concerned for CEO is how to handle conflict in ranks } \\
\mathbf{5}\end{array} \quad \begin{array}{l}\text { The boards want CEOs to improve talent development by more coaching, leading and delegation for the firms which offers } \\
\text { strengthen organization and successful performance }\end{array}$ \\
$\mathbf{6}$ & CEOs hire coaching service for internal and external improvement \\
\hline
\end{tabular}

Tesla CEO is somewhat different than this survey, because of CEO improves talent development by leading and delegation for the firms which offers strengthen organization and successful performance. As (Hofstede, 2018) shows that Individualism is lower in South Africa and CEO has involved various ways of activities (Tesla, 2018). It can be inferred as Tesla's leadership is very unique in style.

\subsubsection{Transformational Leadership and Transactional Leadership}

Elon is the oldest sibling. According to his brother, Kimbol, he was big reader and considerable person while they were growing up in South Africa (Vance, 2013).

Even workers working hard, Tesla had loss of profit as new comer. To make it the most painful thing possible, Elon Musk slept on the factory floor in sleeping bag in early of 2016. Elon Musk involves the highest level with Tesla (JOHNSON, 2017).

Elon and (Rifkin, 2003) who suggested alternative energy, have common background that they studied in the University of Pennsylvania.

His achievement before establishing Tesla was co-founding of online transaction company, PayPal. It was momentous success then acquired by eBay. Elon Musk has great achievement of founding of Space X (Vance, 2013).

By analysis, Elon Musk is very considerable person. His work experience gives Tesla online marketing strategy. His ways of business doing is trending IT tech and demonstrating viable future technology. He involves with wise range of work in Tesla which highlights that he is significantly working harder than other founders.

By analysis of (Hofstede, 2018), power distance would be normal. Individualism must be high because of he involves with wise scope of work. Masculinity maybe normal, he can work in office and he is also an engineer. Uncertainty avoidance maybe high, because of he works for improving autopilot to reduce accident. He maybe mid-term orientation person. US culture in Silicon Valley can be short-term but other Tesla's locations can be long-term perspective. His indulgence rate may be lower than another founder, because of he sacrifices and works for Tesla.

Transformational leadership serves to alter the system by simplify to employees the issues in the present system and a compelling vision of what a new structure of organization should be. Transactional leadership searches to hold down stable statue in the organization though social and economic trades which gain certain target for both of $\mathrm{CEO}$ and employees and is more concerned with individual, group and organizational performance. Elon 
Musk's leadership can be defined as transformational leadership. Tesla is new comer to the market with green technology which weighs on its tremendous vision and it is future orientation.

- 10 Leadership Competencies

The top 10 leadership competencies, grouped into five themes when 195 global leaders were asked to rate 74 qualities, these rose to the top.

Table 4. Top 10 leadership competencies (HBR), 2016

\begin{tabular}{lll}
\hline & & Percentage of Respondents \\
\hline $\mathbf{1}$ & Strong ethics \& safety & $67 \%$ Has high ethical and moral standards \\
$\mathbf{2}$ & Self-organizing & $59 \%$ Provides goals and objectives with loose guidelines/direction \\
$\mathbf{3}$ & & $56 \%$ Clearly communicates expectations \\
$\mathbf{4}$ & Efficient learning & $52 \%$ Has the flexibility to change opinions \\
$\mathbf{5}$ & Nurtures growth & $43 \%$ Is committed to my ongoing training \\
$\mathbf{6}$ & Connection \& belonging & $42 \%$ Communicates often and openly \\
$\mathbf{7}$ & & $39 \%$ Is open to new ideas and approaches \\
$\mathbf{8}$ & & $38 \%$ Creates a feeling of succeeding and failing together \\
$\mathbf{9}$ & & $38 \%$ Helps me grow into a next-generation leader \\
$\mathbf{1 0}$ & & $37 \%$ Provides safety for trial and errors \\
\hline
\end{tabular}

By analysis of (Tesla, 2018), Tesla was established for moves toward a zero-emission future which the statement of business and leadership are high ethical and moral standards.

By analysis of (Vance, 2013), Elon Musk has reliable reference from Kimbol which the statements highlight that his earlier life was considerable.

By analysis of (DYER \& FURR, 2015), he selects employees without their backgrounds such as education and other discrimination. According to Chief Information Officer, Jay Vijayan, He wants the best. Elon Musk said that 'I don't care if they graduated from university or even high school'.

By analysis of (Chafkin, 2016), there are three founders such as Elon Musk, Martin Eberhard and Marc Tarpenning. Regardless other do not concern with business, Elon Musk puts himself into development of Tesla scrupulously.

\subsection{Provides Goals and Objectives with Loose Guidelines/Direction}

By analysis of (Stringham, et al., 2015) Martin Eberhard as co-founder of Tesla states that his vision for the company and the future is to bring their first to the market quickly and efficiently. His vision focused for cost reduction, faster chain supply and simple distribution.

By analysis of (Tesla, 2018), Tesla's vision for faster the world stops using on conventional energy and moves toward zero-emission future, the better. The firm's 'Secret Master Plan' in 2016, introduced low-priced electric vehicle, Model 3. Gigafactory is built for reducing battery cell cost and production is willing to meet innovation goal and creating plenty of workplaces. The firm's vision delivers affordable, clean transportation, clean energy production and will to be more powerful of those. It is vision as Tesla's present goal for the future, leadership states.

\subsection{Clearly Communicates Expectations}

By analysis of (Tesla, 2018), CEO Elon Musk has wide scope of role in Tesla which inter-communication among departments maybe not necessary with his command of several offices. Central management can directly give and receive order and feedback.

By analysis of (Chronowski, et al., 2017), (McCorvey, 2016), (Dana Hull, c. 2012, p. 2017) and (Tesla, 2018), Tesla reaches with customers and communicates via online and with showroom sales people.

By analysis of (Wrolstad, 2017), Tesla reaches to the world with global projects.

By analysis of (Stringham, et al., 2015), partner communication is crucial.

\subsection{Has the flexibility to change opinions}

By analysis of (Vance, 2013), (Stringham, et al., 2015) and (Wrolstad, 2017), Tesla has main innovation from partner R\&D and global projects with other organization. This factor leads that Tesla has the flexibility to change 
opinions from other partners and global projects.

\subsection{Is committed to My Ongoing Training}

By analysis of (Bradley, c. 2012, p. 2017) and (Kight, 2016), Tesla has one crucial technology which is autopilot. The system of autonomous driving is venerable from cyber-attack. Tesla has ongoing training for updates of its software to reinforce of information security and accident avoidance.

\subsection{Communicates often and openly}

By analysis of (Tesla, 2016), Tesla and its employees have positive relationship and this factor leads that communication is internal and effective.

By analysis of (Tesla, 2018), Tesla's communication with consumers is often to public on the internet and its company owned showroom. It is easier to access than conventional market.

By analysis of (Wrolstad, 2017), Telsa reaches to the world by global projects and communicates with the world.

\subsection{Is Open to New Ideas and Approaches}

Elon Musk has always innovative approach to present market with new ideas. He is a founder of several core futuristic companies (Vance, 2013).

Tesla as electric vehicle producer and green energy provider has partnership R\&D with Space $X$. Space $X$ is aerospace company and this factor can be interpreted as Tesla is open to innovative ideas.

\subsection{Creates a Feeling of Succeeding and Failing Together}

When Tesla had tough time by losing working hours on hard jobs and money, Tesla had slept on factory floor in a sleeping bag. CEO of the firm creates a feeling of one organization by suffering together (JOHNSON, 2017).

\subsection{Helps Me Grow into a Next-Generation Leader}

Elon Musk as CEO of Tesla is face of the company and its tremendous branding power (Hansen, 2015). His achievement as Hollywood movie star in Iron man delivers strengths with advertisement and brand value of Tesla (Vance, 2013). His previous experiences as founder of PayPal was successful. These factors lead Elon Musk into a next-generation leader.

\subsection{Provides Safety for Trial and Errors}

There are tremendous issues in autopilot with safety concern (Frick, 2016). There is trial for improving autonomous driving system by building connected system within vehicles and this system operates within real-time updates (Kight, 2016). The company has deployed as many as they can deploy for achieving data of autonomous driving. Software updates provides innovation of driving and reduction of danger and errors.

\section{Findings}

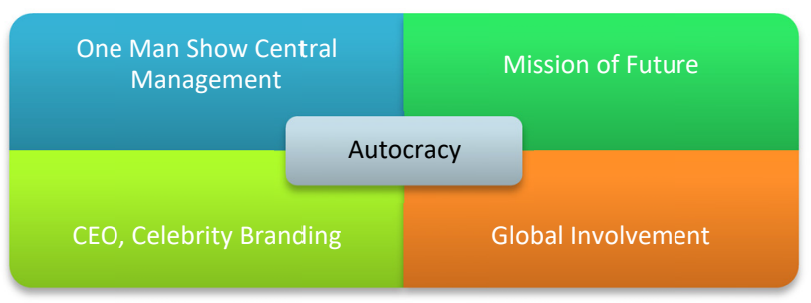

Figure 10. Leadership of Tesla

CEO Elon Musk has role of wise range in Tesla. He is an engineer and he is a CEO. Unlikely, other founder, he works in wise scope which can reduce redundant and errors of inter-department collaboration. This seems to be controlling organization's all sub-departments on the top of hierarchy system.

Tesla has vision to provide the futuristic production to consumers. As new comer to conventional market, the company introduces new features on the vehicles with high-tech software, electric engine and the firm provides new concept of distribution. The company has futuristic vision and mission by its leadership.

Elon Musk is one of popular celebrity and this factor can be one of positive way of how Tesla acquire indirect advertisement. Tesla does not spend money on sponsorship nor commercial. As a leader, Elon Musk has taken significant role for Tesla. 
Tesla is a new comer to the market. Tesla has current technological issues and the firm's trial to solve the problem has involved with other companies as establishing partnership. Tesla's partnership has global involvement. Tesla's leadership is coming from these projects. Tesla has European headiquarter which indicates that there are two leadership in this company.

CEO, Elon Musk has most crucial role and has worked to develop company tremendously. As new comer, Tesla has significant initial cash burning and this factor has led to highly innovative business model of Tesla. Most ideas and works had delivered from Elon Musk. Most data of Tesla are mostly about Elon Musk. By analysis of these factors, this maybe narcissism style of leadership.

\subsection{External Analysis of Economics for Business}

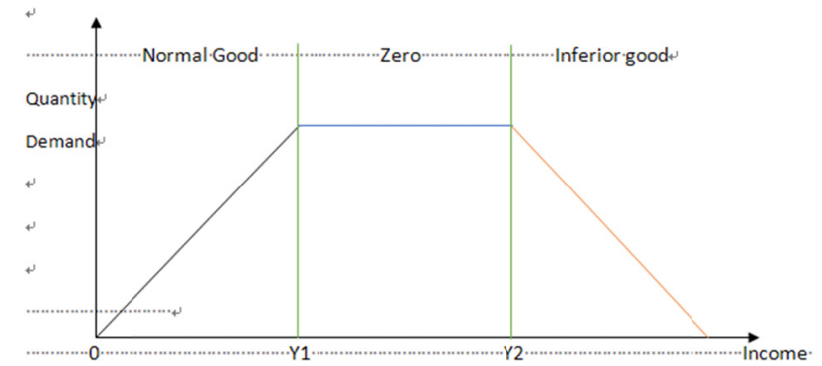

Figure 11. Income elasticity of demand (Griffiths \& Wall, 2011)

If consumers are richer than present, will they buy more Tesla product? The answer is positive about this question. Because of Tesla products can be normal good. When people have no income and no saving at all, it is difficult to purchase the Tesla's products. So, rising income for below middle-class group would be directly affect more demand.

However, this situation within middle-class is Zero. It can be perfectly elastic demand when most consumers have enough money to buy. This will does not affect any phenomenon for changing.

For, upper class, these products can be inferior good. Upper class prefer more luxurious products over Tesla brand. They may pay more attention on private jets or yachts.

Solar power production would be specifically targeted for only home owners and organizations. Thus, this maybe not normal good. It would be zero as perfectly elastic demand (Griffiths \& Wall, 2011).

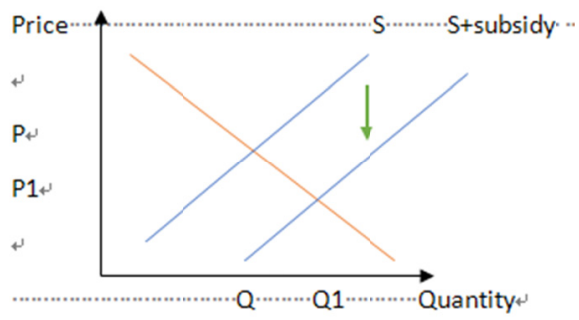

Figure 12. Supply and Demand Curve with Subsidy (Griffiths \& Wall, 2011)

Government regulation and policy can influence business boost and hassle. Government subsidies can down supply curve. This will result equilibrium point downs. The equilibrium point for price will move from P to P1 and for quantity will move from Q to Q1. This policy induces more demand and lower the price. U.S. Department of Energy provides incentives program to encourage more demand for electric vehicle. As well as, USDE offers expansion of network of charging station. The District of Columbia and 45 States in US provides incentives for hybrid and electric cars in range from tax credits or rebates to fleet acquisition goals or exemptions from emission testing. A federal tax credit is up to $\$ 7,500$. Massachusetts offer up to $\$ 25,000$ for business usage.

By consequence, registration of electric vehicle is growing in 18 States and decreasing in 4 States. Generally, more than 600,000 electric vehicles have been sold as total demand increases (NCSL, 2017).

Additionally, the policy provides exemption from emission testing. All cars must pass emission testing in order to acquire approval of registration for operation in Oregon. This reduces effort on fixing cost and saves the time 
for owners. This factor leads more demands (Oregon.Gov, 2018).

According to (CENDROWSKI, 2017), China has rising demand of electric vehicle and Tesla is catching eyes of Chinese customers. However, Telsa's global business in China would be in deep concern. Trade war between US and China is basically imposing tariff on importing goods from each others. This phenomenon will increase potentially price of products. There is $25 \%$ of tariff on Tesla's electric vehicle.

This phenomenon can move supply curve up. This will result equilibrium point goes up. The equilibrium point for price will move from P1 to P and for quantity will move from Q1 to Q. This tariff by the trade war would expect lower demand and higher the price in market place which is vice versa phenomenon of government subsidy effect (Rosenbaum, 2018).

This is one crucial point because of Adam Smith's theory of Invisible hand indicates that great demand is leading economics activities. China is the world second largest market and has highest population in the world. To gain more demand, Tesla needs to cut down cost of production which should meet with economy of scale and Tesla also needs to focus on low priced vehicle, Model 3 is well example. Innovation process and product would be focused with current issue.

Quota is simply political policy that setting restriction for limitation. Previously, US government tried to control oil market by setting import quota on oil (Yergin, 1992).

In emission trading system, there is limitation of approved amount of emission set by the government. This system can be quota system. Previously, we have significant experience and testing on fluctuation of supply and demand curve in terms of couple of oil shocks in the past period (HAY, c. 1970, p. 2017). As same as Oil Quota, cap and trade is tremendous pressure for all of fossil fuel energy industries. This is significant factor for Tesla's expansion on solar power business (WESTERFIELD \& Ellison, 2007). As Tesla announces its products benefit tremendous economic value for isolated islands around the world. Tesla's solar power energy has advantage over cap and trade as well as it suits well for rural areas (Tesla, 2018).

There are leading electric car manufacturers such as General Motors, Nissan, Tesla and Toyota. Especially, Toyota is no.1 brand in the US. Hybrid power engine can be one of substitutes which harness both fossil-fuel power and electric power (MarketLine, 2017). There are issues with oil price and battery. Hybrid can be one of best fit in to reduce problem with full electric vehicle (KOSOWATZ, 2017).

Tesla's products by analysis of income elasticity of demand indicates that these products are not viable technology for below middle-class. So, below middle-class can look for alternative energy sources and transportation. They could simply go with conventional power source which does not require to invest on new innovation. Tesla's facilities are located in where sunshine is abundant such as California and Nevada. However, States in Pacific Northwest does not have much sunlight. The State of Oregon introduced wind power energy. This would be significant threat for Tesla (Sickinger, 2012). In Midwest, biodiesel is natural resource because of it is plain land and it is known as land of corn field. Thus, harnessing biodiesel is useful (Wilhelm, 2015).

Electric vehicle and Solar energy are complement each other. When consumers are looking for EV, they are prone to keen on renewable energy sources. Tesla's internal complement is crucially positive in marketing perspective (Jobbers \& ELLIS-CHADWICK, 2013).

\section{Results}

Economy perspective: Tesla's position in US market is significant. It is the world most innovative company. However, Tesla's products are not for everyone in normal life. These products can be normal good, but the products are more prone to middle-class tech savvy consumers as it is written in (Tesla, 2016). As well as for solar energy products, consumers are supposed to be home owners or organizational groups. Approaching to the market can be burdensome. This factor should lead firms for market segregation.

Politic perspective: By analysis there are two major factors on higher demand for Tesla by the US Government controls. First is subsidies tax credits and incentives on electric vehicle encourage more attention on Tesla. Lastly, Cap and Trade, the emission trading economy policy is one innovation push for conventional businesses and mostly likely the conventional organizations would shift to green energy. There is also advantage from government which is plan for charging station and DEQ testing waiver. Tesla has green light in terms of future perspective.

Market analysis: Tesla has threat from other electric vehicle producers and different type of green energy producers. This factor indicates that Tesla as new comer with high tech into conventional market is not monopoly. Tesla's electric engine can be adopted to most of other manufacturers. This is significant threat for Tesla. Other 
can shift production line to EV. Solar energy takes minute percentage of all energy sources. Other green energy can be Tesla's huge substitute.

Global phenomenon leads Tesla in great threat in US-China trade war. The trade war is imposing massive tariff in order to protect domestic businesses. As one of US products, Tesla has faced significant threat. The review above indicates that Tesla is new comer and the company should reach economy of scale in terms of reduce costs. Tesla indeed needs various ways of approach and innovation.

\section{Conclusions}

Innovation management is significant in the present time. As a new comer to the conventional market. There is existing barrier for later comer. There is tremendous initial cash burning at starts which is significant problem. Tesla has entered the current conventional market place. When Tesla introduced it has different strategy. Tesla's innovation in various ways of trials was indeed needed to overcome existing disadvantage as later comer.

Telsa's products take on incremental innovation, however its software takes on radical innovation. Telsa's products are prone to take attention from innovators, early adopters and tech savvy consumers. Telsa has reached to current market with electric car that has autopilot system. It is significant innovation. Putting mechanical and electrical technology into one transportation is remarkable change

There is wide range of innovation in Tesla. In terms of reach economy of scale and mass production, Tesla has built and plan for Gigafactories around the world. Global expansion such as European headquarter, facilities and global partnership enhance its significant innovation for Tesla products and its process of production.

As electric vehicle manufacturer, Tesla has integration with complement SolarCity which produces solar panels. Tesla products can harness solar energy for home and vehicle. With the energy produced by its solar power, Telsa's EV is winged.

Innovation of Tesla's market approach takes different ways as online website, and its company owned showrooms. As well as, the company does not support any sponsorship nor spending on commercial. This innovation paradigm affects positively on cost reduction.

Tesla is known as world most innovative company. Its innovation and creative climate comes from cost saving management, partnership R\&D and global projects. Tesla's innovation has focused on new model of channel, more reliable software updates and current issue with battery. In order to achieve this working, Tesla has developed considerable relationship with employees. Its employees participate in numerous team projects.
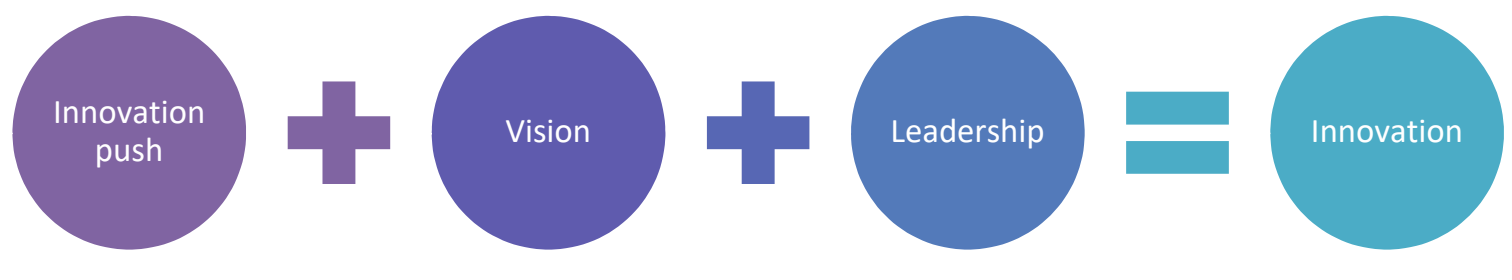

Figure 13. Internal innovation formula

Tesla's CEO role is crucial in the organization and his leadership can be considerable innovation component or push. Elon Musk has 3 countries in his background. Born in South Africa, Canadian-American business person. Vision from leadership is transformational. Transformational leadership encourages the organization to follow futuristic mission. Most of Elon Musk's companies follow mission into future. His previous achievement PayPal was radical innovation. In the present time, Tesla and Space $\mathrm{X}$ are on route with mission for future. Also, it is not difficult to find news article about his plan for future. Hyperloop train and underground transportation as Boring company are significantly futuristic oriented vision of business organizations for normal businesses.

Tesla's innovation is coming from global involvement. Global projects and partnership R\&D are major innovation. As well as Elon Musk's other company Space X is also interconnected with Tesla in terms of collaboration for R\&D. As new comer to current conventional market, Tesla has little experience and previously acquired knowledge and learning, so this global projects and partnership research are tremendously effective to enhance technology of Tesla. Nowadays, Tesla's battery range within single charge is one of the longest yard on the road.

CEO Elon Musk's leadership is central governing styled one man show. His position in Tesla is wide and involve 
with various roles. As a startup company, there is huge initial cash burning. Tesla is required to economize on structure, management, process, branding and commercial. This way, the company can reduce redundancy. Thus, structure of the organization is significantly cost reduction. However, this factor can be tremendous burden for $\mathrm{CEO}$, Elon Musk. He is a man and one man can not do much work, but some people can work more than he can.

There is no celebrity sponsorship nor commercial for Tesla branding. However, CEO Elon Musk starred in the Hollywood movie 'Iron Man'. This is positive ways of indirect branding by key individual.

Overall, leadership of Tesla is Narcissist way of Elon Musk's vision and working. Tesla's leadership and innovation management come from mainly himself. He is the brand of Tesla and he is the face of the company. Elon Musk's role is over-acting in the organization.
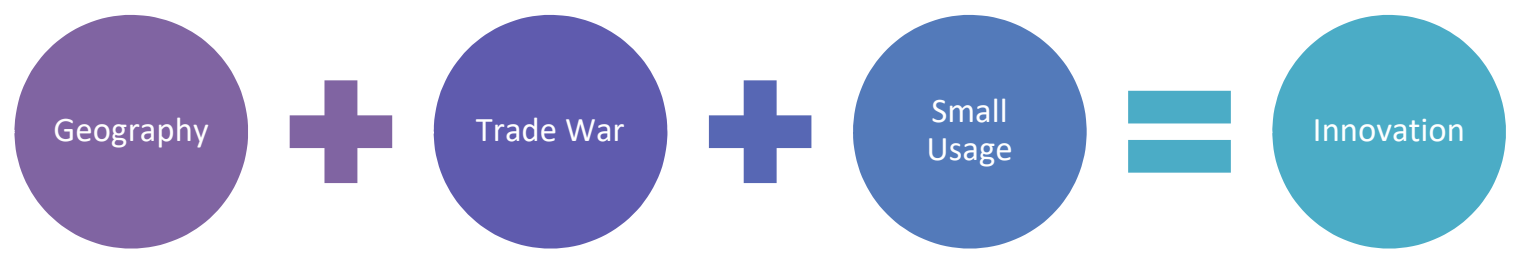

Figure 1. External Innovation Formula

Tesla is world most innovative company and having tremendous attention in the media. However, it is not the leading energy sources. There are numerous sources of energy. Fossil fuel energy is still majority. Renewable energy is small part of entire energy sources. Among renewable energy, it has small portion of total renewable energy usage. Thus, usage of solar power energy is minute. Problem with solar power is it is only suitable where sunshine is abundant. But, it does not suit some States such as Pacific Northwest (Oregon and Washington) and some Midwest States. Geographical factor is crucial for Tesla's business.

US government encourages, and grants benefit for buyers and users of electric vehicle and solar energy. As well as, cap and trade as emission trading policy is opportunity for Tesla. These factors can be green light for Tesla. However, there are some alternative options which can replace Tesla's EV. Especially, no.1 car brand Toyota produces hybrid car and has plan for better electric vehicle in US market. Tesla's market share in US market is not significant but it has tremendous public attention from media. There is opportunity granted from political level and Tesla is in the round with some other electric vehicle manufacturers. So, Tesla should always apply its the latest updates of software and the finest technology of hardware.

Tesla's products are inclined to be in harsh threat from US-China trade war by imposing high tariff. This factor discourage demand by higher price. Tesla has issues which it has not reached economy of scale and it could not produce lower priced electric vehicle. Thus, Tesla's innovation would force lower the cost of production and production line for lower price electric vehicle.

Overall, Tesla's business is not in blue ocean nor red ocean. It entered to niche market which has very little proportion out of entire relevant industry. Tesla's entrance was difficult and taking over high market share would be also difficult not only in the United States, but also in the world.

\section{References}

Anderson, J. (2014). Putting Tesla to the Test. KIPLINGER'S PERSONAL FINANCE.

Bartman, T., 2015. Why Tesla Won't Be Able to Scale. Harvard Business Review, 2-5.

Benson Honig, J. L. (2017). Special Section On Ethics in Management Research: Norms, Identity, and Community in the 21st Century. Academy of Management Learning \& Education, 84-93. https://doi.org/10.5465/amle.2017.0023

Bilbeisi, K. M., \& Kesse, M., C. (2012). Tesla: A Successful Entrepreneurship Strategy.

Cendrowski, S. (2017). Tesla Makes A U-Turn In China. Fortune, 127-137.

Chafkin, M. (2016). The issue with existing batteries is that they suck.

Chronowski, L., McGrath, J., \& Skelton, J. (2017). Tesla Takes on Michigan in Its Fight to Sell Directly to Consumers. The licensing Journal, 16-18.

Cohn, A., Fehr, E. \& GoettE, L. (2015). Strategy Tesla's Not As Disruptive As You Might Think. Harvard Business Review, 22-23. 
Cornell, B., \& Damodaran, A. C. (2012). Tesla: Anatomy of a Run-Up. Practical Applications, 43-46.

Crane, D. A. (2014). Tesla and The Car dealers' lobby. Regulation, 10-14.

Dana Hull, E. A. C. (2012), Tesla Takes on the Dealerships.

DUNN, B. (2016). The stars are beginning to line up for electric vehicles. Canadian Sailings, 43.

Dyer, J., \& Furr, N. (2015). Tesla's Secret Formula. Forbes, 91-118.

EPA (2014). Global Greenhouse Gas Emissions Data. Retrieved from https://www.epa.gov/ghgemissions/global-greenhouse-gas-emissions-data

Frick, W. (2016). Tesla, Autopilot, and the Challenge of Trusting Machines. Harvard Business Review, 2-4.

Ghemawat, P. (2013). Differences Across Countries: The GAGE Distance Framework. Harvard Business School Press, 1-35.

Giuliana, B. (2015). Tesla Is Betting on Solar, Not Just Batteries. Harvard Business Review.

Griffiths, A., \& Wall, S. (2011). Economics for Business \& Management (3rd ed.). Essex: Pearson.

Hansen, R. B. (2015). How Tesla, Under Armour, and Sonos Do Branding. Harvard Business Review, 2-4.

Hay, G. A. (1970). Import Controls on Foreign Oil: Tariff or Quota?

Hoffman, A. (2012). Tesla Takes on the Dealerships-and GM. Bloomberg.com.

Hull, D.(2012). For Tesla, Stores Are Classrooms, Too. Business Week.

Hull, D., Welch, D. \& Higgins, T., c. 2012, p. 2017. Tesla Takes on the Dealerships-and GM. Business Week.

IEA. (2017). CO2 emissions from fuel combustion; Overview. IEA, 1-13.

Jemma Oeppen, A. J. (2014). Collaborating for success: managerial perspectives on co-branding strategies in the fashion industry (pp. 925-948). https://doi.org/10.1080/0267257X.2014.934905

Jobbers, D., \& Ellis-Chadwick, F. (2013). Principles and Practice of Marketing (7th ed.). McGraw-Hill Higher Education.

Johnson, D. (2017). Responding to safety scrutiny Tesla CEO is more direct than many execs. Industrial Safety \& Hygiene News.

Knights, C. (2017). Tesla planning up to three additional gigafactories. Corporate Knights, 16.

Kosowatz, J. (2017). Electric Enabler. American Society of Mechanical Engineers. https://doi.org/10.1115/1.2017-Dec-6

Kristopher, O., \& Keller, M. G. D. (2016). Let Your Banner Wave? Antecedents and Performance Implications of Retailers' Private-Label Branding Strategies. Journal of Marketing, 1-23. https://doi.org/10.1509/jm.15.0154

Mangram, M. E. (2012). The globalization of Tesla Motors: a strategic marketing plan analysis. Routledge, 290-312. https://doi.org/10.1080/0965254X.2012.657224

Papierz, M. (2017). Apple Products: A Discussion of the Product Life Cycle. International Conference on Management Science and Management Innovation.

Rahman, M. (2014). Differentiated brand experience in brand parity through branded branding strategy. Journal of Strategic Marketing, 603-615. https://doi.org/10.1080/0965254X.2014.914061

Ridder, H. G. (2017). The theory contribution of case study research designs. https://doi.org/10.1007/s40685-017-0045-z

Rifkin, J. (2003). The Hydrogen Economy: The Creation of the Worldwide Energy Web and the Redistribution of Power on Earth. https://doi.org/10.1016/S1471-0846(03)80112-9

Saunders, M., Lewis, P. \& Thornhill, A. (2009). Research methods for business students. 5 ed. Essex: Pearson Education Limited.

Sickinger, T. (2012). The cost of green: Huge eastern Oregon wind farm raises big questions about state, federal subsidies. Oregon Live.

Stringham, E. P., Miller, J. K., \& Clark, J. (2015). Overcoming Barriers to Entry in an Established Industry: TESLA MOTORS. https://doi.org/10.1525/cmr.2015.57.4.85 
Swiegers, I. (2017). Buying into the vision of a better world. marketplace pro pick.

TheWorld Bank. (2018). World Development Indicators database. The World Bank Group data.

Tidd, J., Bessant, J., \& Pavitt, K. (2005). MANAGING INNOVATION Integrating Technological, Market and Organizational Change. John Wiley \& Sons Ltd.

Tumele, S. (2015). CASE STUDY RESEARCH. International Journal of Sales, Retailing and Marketing, 68-78.

Vance, A. (2012). A Bus Company Aims to Follow the Tesia Model. Bloomberg Businessweek.

Vance, A. (2013). Elon Musk, Man Of Tomorrow. Bloomberg Businessweek.

Vance, A., C. (2012). Can Elon Musk, Silicon Valley's favorite carmaker, win over the rest of the world? Bloomberg Businessweek, 48-52.

Ventura, L., 2017. Reforms Give Major Boost To Business Ranking. Global Finance Joint Venture.

Westerfield, B., \& Ellison, S. (2007). Eba Climate Change Primer: Cap And Trade. Foundation for the Energy Law Journal, 173-193.

Wieczner, F. (2015). Tesla Investors Do The Electric Slide. Fortune, 51-52.

Word Bank. (2017). World Bank Commodities Price Forecast (nominal US dollars).

Wrolstad, J. (2017). Problem solving through teamwork. Cornell SC Johnson College of Business.

Yergin, D. (1992). 1959 U.S. Quota on Foreign Oil Imports.

Yin, R. K. (2018). Case Study Research And Applications Design and Methods (6th ed.). Los Angeles: SAGE.

\section{Copyrights}

Copyright for this article is retained by the author(s), with first publication rights granted to the journal.

This is an open-access article distributed under the terms and conditions of the Creative Commons Attribution license (http://creativecommons.org/licenses/by/4.0/). 